\title{
PROBATION IN PHILADELPHIA: JUDICIAL DECISION AND CONSTITUTIONAL NORMS *
}

Conviction of a criminal offense may or may not result in a term of imprisonment. For many defendants, the question most critical to their personal liberty may be that of whether to grant probation, or the later question whether to revoke probation once granted. This Comment seeks to ascertain and explore the factors, both legal and extralegal, that are in fact determinative of such questions, and to analyze the constitutional constraints that define the permissible bounds of the decision-making process.

The focus of this study was determined by two aspects of the probationary process. Most criminal defendants are convicted. But although disposition is the element in the criminal process most crucial to the convicted offender, and although the law has been going through a period where sensitivity to defendants' rights has led to the development of a constitutional law of criminal procedure applicable to all phases of the criminal process from arrest to adjudication of guilt or innocence, once the Rubicon of adjudication has been crossed, the convicted offender has a right only to counsel. ${ }^{1}$ The second aspect of probation that marked the focus of this paper was the dearth of knowledge about either the costs or effects of probation. Recommendations for the future development of the law can only be based on some notions of the value of probation as an alternative to incarceration; but the factors determinative of that value are not readily, if even possibly, ascertainable.

One ascertainable sphere of knowledge is what the trial judges of Philadelphia think about the cost and value of probation. Since these are the men who will choose between incarceration and probation within any system suggested by this Comment, their ideas about cost and effectiveness are most relevant in the formulation of recommendations. Without considering judicial attitudes, one could not know, for example, whether the practical result of more formalized procedures for granting or revoking probation would be a better decision-making process or much less probation."

* This Comment is the result of a field study during the summer of 1967 , made possible by the Thomas Skelton Harrison Foundation.

1 See Mempa v. Rhay, 389 U.S. 128 (1967) (constitutional right to counsel at sentencing).

2 In order to ascertain the views of Philadelphia trial judges on the various aspects of probation, a series of interviews was conducted with the judges of the Court of Common Pleas and judges of the County Court. Both the courts have jurisdiction over adult criminal cases, but only the Court of Common Pleas can hear murder cases. Requests for interviews were sent to all 29 Common Pleas, and all 19 County Court judges. Sixteen judges of Common Pleas Court were interviewed. Nine of the County Court judges were interviewed. Four of the 10 County Court judges not interviewed declined on the ground that they had not sat on criminal cases and felt that they therefore could not make sufficiently informed suggestions on probation. 


\section{Probation in its present form probably began in this country}

The interviews that form the basis of this paper's comments on judicial attitudes thus came from over one half of the Philadelphia trial judges sitting on adult criminal cases. This would seem to be a significant percentage, unless one assumes that willingness or unwillingness to discuss probation is itself indicative of a skewed range of views on the subject. The wide range of opinion and attitudes expressed by those judges interviewed tends to suggest otherwise. Indeed, the inability to obtain interviews with some judges could probably be more accurately accounted for by the fact that these interviews were held for the most part during the summer months when many judges were on, or just returning from, vacation.

In requesting these interviews, it was stipulated that everything said was off the record in the sense that no remarks would be attributed to any specific judge, and that opinions expressed would be grouped and attributed only to the trial judges generally. The interviews themselves were not conducted from a list of predetermined questions. Indeed, many of the questions used in later interviews were suggested by answers given in earlier ones. Thus, not all questions were posed to all judges interviewed. The interviews, however, did proceed generally along similar lines in order to get comparative responses to particular problems. In order to get such responses it was often not satisfactory to pose a question in general terms, such as what practice the judge did or would follow if a defense attorney challenged the contents of a presentence report. In order to get any response to such inquiries, it was necessary to refine the hypothetical. Certain attitudes could be ascertained only by asking a question indirectly: or by bearing on a point from opposite direction. For example, of 20 judges asked whether the facilities available for supervision played a part in determining whether or not they sentenced a man to prison or placed him on probation, all but 2 answered negatively. Yet of the same 20 , when asked if improved facilities for supervision would result not only in more successful probations but also more offenders being placed on probation, all but 5 answered positively.

While it appeared that the responses of the judges were candid, it was not possible to obtain any information at all as to what part the defendant's plea played in determining whether or not to impose probation.

The following judges of the Courts of Common Pleas and County Courts granted interviews to this writer:

The Honorable Edward J. Bradley, Judge of the Court of Common Pleas

The Honorable Francis S. Brown, President Judge of the Court of Common Pleas

The Honorable Vincent A. Carroll, President Judge of the Court of Common Pleas

The Honorable Ethan Allen Doty, Judge of the Court of Common Pleas

The Honorable Joseph E. Gold, President Judge of the Court of Common Pleas

The Honorable Stanley M. Greenberg, Judge of the Court of Common Pleas

The Honorable Peter F. Hagan, President Judge of the Court of Common Pleas

The Honorable D. Donald Jamieson, President Judge of the Court of Common Pleas

The Honorable Herbert S. Levin, President Judge of the Court of Common Pleas

The Honorable James T. McDermott, Judge of the Court of Common Pleas

The Honorable John J. McDevitt, President Judge of the Court of Common Pleas

The Honorable Thomas M. Reed, Judge of the Court of Common Pleas

The Honorable Joseph Sloane, President Judge of the Court of Common Pleas

The Honorable Edmund B. Spaeth, Jr., Judge of the Court of Common Pleas

The Fonorable Theodore B. Smith, Jr., Judge of the Court of Common Pleas

The Honorable David I. Ullman, Judge of the Court of Common Pleas

The Honorable Adrian Bonnelly, President Judge of the County Court

The Honorable Clifford S. Green, Judge of the County Court

The Honorable Theodore S. Gutowicz, Judge of the County Court

The Honorable Gregory G. Lagakos, Judge of the County Court

The Honorable Joseph L. McGlynn, Jr., Judge of the County Court

The Honorable Samuel Rosenberg, Judge of the County Court

The Fonorable Benjamin W. Schwartz, Judge of the County Court

The Honorable James L. Stern, Judge of the County Court

The Honorable Charles Wright, Judge of the County Court

[These interviews are hereinafter cited as Interviezes of Judges.] 
through the work of a Boston cobbler named John Augustus. In August, 1841, Augustus offered to stand bail for a man convicted of being a common drunkard. The defendant was ordered to come before the court three weeks later for sentencing. Upon the defendant's return the judge imposed a nominal fine of one cent rather than a jail sentence. This device of recognizance, along with benefit of clergy and judicial reprieve, had often been used as a method for ameliorating the harshness of the criminal law. What distinguished the practice of Augustus in this first case, and in the nearly 2,000 others that were to follow until his death in 1859, was his attempt to choose for whom he stood bail on the basis of an estimate of the likelihood of their rehabilitation. He tried to make inquiry into their character and past records. He undertook the responsibility to see that his charges went to school or obtained employment, and also kept records of their progress, including reports to the court when required. ${ }^{3}$

In the hundred-odd years since the death of the Boston cobbler, probation has become a significant element in the administration of the criminal law. In 1965, 8,049 adult criminal cases were processed in Philadelphia. Of the 4,040 adults convicted, 2,128 were either placed on probation or had their sentence suspended. ${ }^{4}$

The Pennsylvania probation statute attained its present form in $1941 .^{5}$ Past limitations with respect to the classes of criminals eligible for probation were removed except in the case of first degree murder.

Whenever any person shall be found guilty of any criminal offense by verdict of a jury, plea, or otherwise, except murder in the first degree, in any court of this Commonwealth, the court shall have the power, in its discretion, if it believes the character of the person and the circumstances

3 B. Kay \& C. Vedder, Probation and Parole 3-52 (1963). See generalfy C. Chute \& M. Beil, Criare, Courts and Probation (1956); R. Clegg, Probation and Parole 1-51 (1964).

4 Annual Report Clerk of Quarter Sessions and County Court (1965). The last year for which this annual report is complete is 1966. The 1966 report, however, gives only the number of cases processed and the judgment. The figures are not broken down by disposition of convicted offenders, as they are in the 1965 report. See ANnual Report Clerk of Quarter Sessions ANd County Court (1966).

5 The first adult probation statute in Pennsylvania was enacted in 1909, but its benefits were withheld from those convicted of murder, kidnapping, incest, sodomy, rape, assault with intent to rape, poisoning, arson, or burglary of an inhabited dwelling house, and all those previously imprisoned for a crime. PA. STAT. ANN. tit. 19, $\$ \$ 1081-1085$ (1964). In 1911 another statute was passed, which required that probation be imposed for a definite period of time, and which granted trial judges the discretionary power to require defendants to pay a sum of money to the state as a condition of probation, provided that such sum did not exceed the maximum fine for the offense. PA. STAT. ANN. tit. 19, \&1051 (1964). In 1925 the statute was amended to provide expressly that the requirement to pay allowed by the 1911 statute was not to be considered a fine, and that such a requirement did not prevent a trial court from subsequently sentencing the probationer in the event of revocation. The amendment was in response to Commonwealth v. Ciccone, $84 \mathrm{~Pa}$. Super. 224 (1924), which held that the imposition of a fine as a condition to probation barred the imposition of a further sentence on the theory that the payment of a fine was punitive and took the place of sentence. 
of the case to be such that he is not likely again to engage in a course of criminal conduct and that the public good does not demand or require the imposition of a sentence to imprisonment, instead of imposing such sentence, to place the person on probation for such definite period as the court shall direct, not exceeding the maximum period of imprisonment allowed by law for the offense for which such sentence might be imposed. ${ }^{6}$

According to the statutory mandate, the decision to grant probation should be based on a finding that the defendant is not likely to engage in future criminal conduct and that the "public good" does not require his imprisonment. Probation, however, is conceived of not merely as a disposition of a certain category of offenders, but as a rehabilitative tool as well. ${ }^{7}$ The probationer's conduct is circumascribed by placing various conditions on probation, violations of which are grounds for revocation and the imposition of sentence. ${ }^{8}$ The nature of permissible conditions on probation has been limited by two Pennsylvania cases holding that conditions of probation must not be "punitive." ' Such cases, of course, are using "punitive" to imply a retributive purpose. Probation itself, no matter what its goal, is punitive to the extent that its conditions restrict the life of the probationer. The theory of these cases is, therefore, probably a limitation upon conditions that are puntive in purpose rather than effect.

One must note, however, that the statute provides that even after a positive finding on the elements that would indicate probation, the court "shall have the power" to place on probation, rather than "shall" place on probation. Since the language indicates that the decision to grant probation is solely within the discretion of the trial judge, an offender is without any right to probation and it would be difficult to find a basis upon which its denial by a trial court could be subject to appellate review.

\section{The Decision to Grant or Not to Grant Probation}

\section{A. The Presentence Investigation Report}

In accord with procedures generally prevailing throughout the country, Pennsylvania law requires that, unless a judge specifically requests otherwise, a presentence investigation and report be made

6 Pa. Stat. Ann. tit. 61, §331.25 (1964).

7 See B. Kay \& C. Vedder, Probation and Parole 53-122 (1962) ; Best \& Birzon, Conditions of Probation: An Analysis, 51 GEo. L. J. 809 (1963).

8 See C. Chute \& M. Bell, Crime, Courts and Probation (1956); R. Clegg, Probation and Parole (1964) ; Best \& Birzon, Conditions of Probation: An Analysis, 51 GEO. L. J. 809 (1963).

9 Commonwealth v. Vivian, 208 Pa. Super. 330, 222 A.2d 739 (1966) ; Commonwealth v. Ciccone, $84 \mathrm{~Pa}$. Super. 224 (1924). 
upon every defendant convicted of an offense punishable by a sentence of two years or more..$^{10}$ Complying with the recommendations of the Philadelphia Quarter Sessions Court, ${ }^{11}$ the presentence report contains a statement of the present offense and the offender's previous court and institutional records; statements by the complainant and defendant concerning the present offense; any aggravating or mitigating circumstances of the present offense; and information concerning codefendants, if any, and their relationship with the subject of the report. The report also includes information on the offender's early life and education, employment and economic history, character, habits, leisuretime activity, marital history, military experience, mental and physical condition, family background, and the community's attitude toward the offender. The report concludes with a statement of the resources available for treatment and the recommendation of the probation officer. ${ }^{12}$ Thus, the report which passes into the hands of the sentencing judge is a melange of information, ranging from the relative objectivity of figures and public records to the impressionistic, evaluative summary and recommendations of the investigator.

The report is conceived of as a pivotal element in shaping the judge's disposition of the defendant, ${ }^{13}$ and while actual influence upon the sentencing judge may be somewhat less than intended, ${ }^{14}$ there is no doubt that, in some cases, the presentence report will mean the difference between incarceration and the relative freedom of probation. ${ }^{15}$ The fact that this report may be an important factor in this crucial step in the criminal process raises specific problems for the lawyer.

10 PA. Stat. ANN. tit. 61, \$ 331.17a (Supp. 1967). It has been estimated that nationally a presentence report is almost always used in the sentencing of felons. National Council on Crime \& Delinguency, Correction in the United StatesA Survey For the President's Commission on Law Enforcement and Addinistration OF Justice 170 (1966). The 1966 Director of THE AdMINISTRATIVE OFFICE OF THE UNITED STATES COURTS ANNUAL REPORT reports that presentence reports are used in $85 \%$ of convictions.

11 Survey Committee Report on Probation Department of Quarter Sessions COURT OF PHILADELPHIA (1962).

12 See id. at 39.

$13 \mathrm{Id}$. at 40.

14 Interviews of Judges. Eleven of 25 judges indicated that they generally formed a tentative impression of proper disposition of a defendant before the receipt of the presentence report, through observation of defendant at trial. Of these 11 judges, 8 said that information in the report on past criminal record plus their own observation of a defendant were generally the most important elements in shaping sentence. Two judges, not among the 11, said that past criminal record was the only information in the presentence report that they considered.

15 The importance of sentencing procedures to each convicted defendant is obvious. The role of sentencing in the administration of criminal justice as a whole is also great. It is the only significant formal procedure that the large majority of criminal defendants undergo. In 1966, for example, $85 \%$ of the 28,405 persons upon whom the federal district courts passed judgment pleaded either guilty or nolo contendere. 1966 Director of tHe ADMinistrative OfFice of the UNited States Courts ANNUAL REPORT 220. 


\section{Availability of the Report to the Defendant (in Law)}

The Supreme Court in 1949 considered the use of presentence reports, in Williams $v$. New York. ${ }^{16}$ In that case a jury had recommended life imprisonment, but the trial judge, acting pursuant to a state statute leaving the court with the power to impose a death penalty, did so notwithstanding the jury's recommendation. In fixing sentence, the judge stated that he was relying on information concerning the convicted person's character and past involvement with the law. The rules of evidence would have kept such information from the jury prior to its verdict. The use of such information was sanctioned, however, by the New York Criminal Code, ${ }^{17}$ which directs the trial court to cause the defendant's past criminal record, together with reports of any mental and physical examinations that have been made, to be brought before it and provides that the court may seek any additional information that would aid it in determining sentence.

Appellant, challenging the statute on its face, contended that its failure to afford him an opportunity to confront his accusers constituted a denial of due process. There was no challenge to the accuracy of the judge's statements, nor was an opportunity requested to refute or discredit them. ${ }^{18}$ The Court upheld the statute in the situation presented.

Williams has been read as supporting the confidentiality of the report and as denying the defendant the opportunity to controvert its contents. $^{19}$ Such an interpretation undoubtedly stems from dicta in the opinion recognizing the burden of requiring a full hearing on all the matters contained in the report. ${ }^{20}$ These dicta, however, only suggest that the full panoply of evidentiary rules is not required in a hearing on the contents of a presentence report; in no way do they sanction the complete withholding of the report from the defendant. ${ }^{21}$ In fact, Townsend v. Burke ${ }^{22}$ seems to support the contention that due process requires at least that the defendant be made aware of the contents of the report.

In Torensend, decided in 1948, a defendant who had pleaded guilty to charges of armed robbery and burglary was sentenced by a judge misinformed about his prior criminal record. The sentence was

16337 U.S. 241 (1949).

17 N.Y. CoDE CRIM. Pro. $\$ 482$ (McKinney 1958).

18337 U.S. at 244.

19 See Note, Right of Criminal Offenders to Challenge Report Used in Determining Sentence, 49 Colum. L. REv. 567 (1949), which suggests that the decision in the case might deny to a defendant the right to controvert material within the report. While it is true that the New York statute had been construed to deny the opportunity to challenge the report, it has already been noted that no challenge was, in fact, made in Williams.

20337 U..S. at 250.

21 Of note is a statement in Williams that the decision was "not to be accepted as a holding that the sentencing procedure is immune from scrutiny under the due process clause." Id. at 252 n.18.

${ }_{22} 334$ U.S. 736 (1948), cited with approval in Williams, 337 U.S. at 252 n.18. 
within the maximum allowed by the state statute. The Supreme Court, however, asserted that it could not speculate on the degree of emphasis given the false information and concluded that such sentencing failed the test of due process. The opinion continued:

Counsel, had any been present, would have been under a duty to prevent the court from proceeding on such false assumptions and perhaps under a duty to seek remedy elsewhere if they persisted. Consequently, on this record we conclude that, while disadvantaged by lack of counsel, this prisoner was sentenced on the basis of assumptions concerning his criminal record which were materially untrue. Such a result, whether caused by carelessness or design, is inconsistent with due process of law, and such a conviction cannot stand. ${ }^{23}$

Some authorities have interpreted Tozensend as concerning only the necessity for the presence of counsel at sentencing. ${ }^{24}$ This position can draw some support from the tone of the opinion in Williams indicating that the usual requirements of procedural due process are not mandatory at sentencing. Furthermore, a recent Supreme Court decision, Specht v. Patterson, ${ }^{25}$ not only reaffirmed Williams in dictum, but stated that Williams was authority for the broad proposition that "the Due Process Clause of the Fourteenth Amendment did not require a judge to have hearings and to give a convicted person an opportunity to participate in those hearings when he came to determine the sentence to be imposed." 26

Specht's broad reading of Williams was not necessary to the decision and does not seem viable. The right to counsel guaranteed by the sixth amendment applies in state criminal cases through the due process clause of the fourteenth amendment, ${ }^{27}$ and the Supreme Court held in Mempa $v$. Rhay ${ }^{28}$ that the right applies at sentencing. Williams itself cited Townsend without disparagement of any sort. Most important, the language in Torensend is unequivocal: sentencing a person "on the basis of assumptions concerning his criminal record which were materially untrue . . . , whether caused by carelessness or design, is inconsistent with due process . . . ."29 Thus, the

23 Id. at 740-41.

24 See discussion of various interpretations of Tozensend in Note, Procedural Due Process at Judicial Sentencing for Felony, 81 HARV. L. REv. 821, 826 (1968). For a narrow reading of Tozensend, see Harris v. Langlois, 98 R.I. 387, 392, 202 A.2d 288, 291, cert. denied, 379 U.S. 866 (1964) ; W. BeAveY, THE RIGHT to CoUNSEL IN AMERICAN COURTS 184-85 (1955).

25386 U.S. 605 (1967).

$28 \mathrm{Id}$. at 606.

27 Gideon v. Wainwright, 372 U.S. 335 (1963).

28389 U.S. 128 (1967).

29334 U.S. at 740-41. 
decision requires not only the presence of counsel but also that sentencing be based on factually correct information, ${ }^{30}$ or, at least, that the defendant be given an adequate opportunity to dispute an inaccurate report. ${ }^{31}$ This in turn implies that at least the portion of the report used by the judge in setting sentence must be disclosed to the defendant as a matter of right. ${ }^{32}$ Otherwise, the duty of counsel referred to in Townsend $v$. Burke ${ }^{33}$ could not be discharged effectively. ${ }^{34}$

The area is, however, somewhat uncertain. Viewing Townsend and Williams together, it appears that the Supreme Court has sanctioned the use of an ex parte presentence report ${ }^{35}$ but impliedly granted

30 United States ex rel. Jackson v. Myers, 374 F.2d 707 (3d Cir. 1967) ; Kadish, The Advocate and the Expert-Counsel in the Peno-Correctional Process, 45 MINN. L. Rev. 803 (1961) ; Note, Right of Criminal Offenders to Challenge Reports Used in Determining Sentence, 49 Colum. L. Rev. 567, 570 (1949); Note, Due Process and Legislative Standards in Sentencing, 101 U. PA. L. REv. 257, 265-68 (1952).

31 See 334 U.S. at 740-41. The Court did, however, take pains to point out that not every incorrect determination of fact was necessarily a denial of due process. Id. at 741 .

32 But see Cafeteria and Restaurant Workers Union Local 473 v. McElroy, 367 U.S. 886, 898 (1961) (right to government employment) :

We may assume that [petitioner] could not constitutionally have been excluded from the Gun Factory if the announced grounds for her exclusion had been patently arbitrary or discriminatory .... It does not follow, however, that she was entitled to notice and a hearing when the reason advanced for her exclusion was, as here, entirely rational . . . .

Under the reasoning of this case, there may be a right to a hearing on the information in the presentence report only when the trial judge announces grounds for his sentencing decision that are arbitrary or false. The majority opinion in McElroy was strongly criticized in a dissenting opinion by Mr. Justice Brennan, joined by the Chief Justice and Justices Black and Douglas:

Such a result in effect nullifies the substantive right-not to be arbitrarily injured by government-which the Court purports to recognize. What sort of right is it which enjoys absolutely no procedural protection . . .? She may be the victim of the barest calumny, perhaps even the caprice of the government officials in whose power her status rested completely.

Id. at 900-01.

$$
33334 \text { U.S. } 736 \text { (1948). }
$$

34 One student comment has argued that subsequent Supreme Court decisions infuse Tozenisend with a broad scope. Note, Procedural Due Process at Judicial Sentencing for Felony, 81 HARv. L. REv. 821, 827-29 (1968). The argument centers on an analogy between the supposed "scientific" treatment of juveniles and the supposed "scientific" treatment of convicts at sentencing, both of which constitute the rationale for not requiring customary modes of procedural due process in their respective areas. Compare discussion of the traditional justifications of nonadversary juvenile proceedings in Mack, The Juvenile Court, 23 HARv. L. REv. 104 (1909), with Williams v. New York, 337 U.S. 241, 249-50 (1949) (due process proscription of the use of ex parte information not applicable to sentencing because "[ $t]$ o deprive sentencing judges of this kind of information would undermine modern penological procedural policies that have been cautiously adopted throughout the nation after careful consideration and experimentation"). The Supreme Court has, however, recently demonstrated that it will not necessarily subordinate traditional norms of procedural due process for the sake of paternalistic, "scientific" treatment. See In re Gault, 387 U.S. 1 (1967); Kent v. United States, 383 U.S. 541 (1966). Thus it is argued that "[t] he disenchantment with 'scientific' treatment of juveniles .. . . should apply as well to the 'scientific' sentencing of adults." Note, Procedural Die Process at Judicial Sentencing For Felony, 81 HaRv. L. Rev. 821, 829 (1968).

35 See also State v. Alford, 98 Ariz. 124, 402 P.2d 551 (1965). Bust see People v. O'Riordan, 21 I11. App. 2d 309, 157 N.E.2d 780 (1959). 
defendants some level of access to its contents. The question what procedures would be constitutionally required in the event of a challenge to its accuracy remains open.

\section{Availability of the Report to the Defendant (in Fact)}

Among the Philadelphia trial judges who contributed to this study, ${ }^{36}$ opinions on the desirable legal rules concerning confidentiality of the presentence report were diverse, ranging from a belief that the defendant should be given no right to see the report to a belief that he should always be allowed to see it. Opinions on the present state of the law in the area ranged from a belief that the defendant has no right of access to the report to a belief that such a right is presently his. ${ }^{37}$

Two of the judges said that they would always resist a request for the report. They said that if anything contained in the report influenced their disposition of the case, they would summarize the conclusion(s) of such material and make reference to it in court before sentencing, thereby giving the defendant an opportunity for rebuttal. The possibility for effective rebuttal offered by such a practice can be illustrated by the following example. If the report contained information from the defendant's wife that defendant was habitually drunk and abusive toward his family, and such information was in any way determinative of sentence, these two judges in sentencing would refer to his negative conduct toward his family but not to specific instances discussed in the report for fear of exposing the identity

${ }^{36}$ See note 2 supra.

37 Two judges were of the opinion that there is a right to know the contents of the presentence report; they stated that they made sure that defense counsel was given a copy of the presentence and neuro-psychiatric reports whether or not they were requested. Their belief in defendant's right to the contents of the judges' sentencing reports stemmed from two cases: Specht v. Patterson, 386 U.S. 605 (1967); United States ex rel. Gerchman v. Maroney, 355 F.2d 302 (3d Cir. 1966). Such an inference from these two cases is, however, questionable.

In Maroney, the Court of Appeals for the Third Circuit held that the ex parte use of a report submitted to the trial judge by the Commissioner of Mental Health of the Department of Public Welfare to sentence the defendant under the Barr-Walker Act, PA. Stat. AnN. tit. 19, §\$1166-1174 (1964), as anended \$§ 1168, 1172 (1965), was a denial of the right of confrontation incorporated and made mandatory on the states by the due process clause of the fourteenth amendment. The decision, however, was based on the theory that the Barr-Walker Act was an independent criminal proceeding for which a finding beyond that of the original charge was necessary. The court not only refused to view the proceedings under the Act as a sentencing pursuant to criminal conviction, but expressly added that the right of confrontation would not exist in such a proceeding.

It is undoubtedly true that the guarantee of the right of confrontation and cross-examination does not apply to sentencing pursuant to a criminal conviction. . . The rule has not yet been fully clarified as to civil commitment . . But the present case falls in neither of the categories because the Barr-Walker proceedings are criminal rather than civil in nature and constitute an essentially independent rather than a sentencing proceeding.

United States ex rel. Gerchman v. Maroney, supra, at 309.

The same analysis would undercut any reliance on the Supreme Court decision in Specht v. Patterson, 386 U.S. 605 (1965), in which the Court struck down the Colorado Sex Offender Act for the same reasons as those stated in Maroney. 
of the informant. The primary objection of both judges to making the report available was that it might engender hostility toward the source of the information and lay the groundwork for further trouble from the defendant. Withholding the source of information from the defendant, however, denies him the opportunity to challenge the information by impeaching its source. One judge denied that this was much of a handicap in rebutting the conclusions stated to him in court. The other, while acknowledging that withholding the source did disadvantage a defendant slightly, claimed that a mere summary of relevant materials in court before sentencing was as far as the courts could go in the direction of disclosure without engendering the greater evil of causing trouble between defendants and contributors to the reports.

The largest group of judges (21 of 25 interviewed) believed that defendants do not, under the present state of the law, have a right to the presentence report, that in almost all cases they should be given the report, and stated that it was in fact their practice to make a copy of the report available to defense counsel, but that they were not in favor of giving access to the report as a matter of right. The judges in this group thought that there were some situations in which they might wish either to excise portions of the report or withhold it altogether and felt that it would be difficult either to draft a statute or to create a rule by court decision that would be sensitive enough to particular circumstances. The categories of information that these judges indicated they might wish to withhold from the defendant are (1) information, such as the neuro-psychiatric evaluation and the investigator's recommendation, that might adversely effect the relationship between the defendant and those charged with his rehabilitation; (2) information that might adversely affect the defendant's relationship with his family and community, for example, derogatory reports the contents of which would indicate a source such as a close family member or an employer; and (3) information that might be curtailed in the future if the sources were divulged. As examples of the third category, the judges revealed a concern for the continued flow of information from the files of the Federal Bureau of Investigation and the armed services. ${ }^{38}$

Of the judges who claimed that it was their practice to make the report available, but who still desired discretion to withhold it, the majority claimed they would never withhold information to cover up its source, believing that if the information was significant enough to affect the sentence in any way, the source should be revealed. These judges would, however, sometimes excise the neuro-psychiatric evalua-

38 It is difficult to imagine why loss of anonymity would cause such sources to run dry. Surely it could not be because of fear of reprisal. Nonetheless, these were the sources that the judges mentioned most prominently. 
tion and the case worker's recommendation. A majority of this group said that if they could not reveal the information because of the agency from which it came, they would not feel free to use it in determining sentence.

The remaining 10 judges, although not believing that the law presently compels them to make the presentence report available, always do make sure that a copy is supplied to defense counsel whether or not he so requests. These judges all believe that the law should grant the defendant access as a matter of right. The judges in this group acknowledged that there might be occasions when they could excise portions of the report to serve some desirable goal without substantially hindering defendant's ability to rebut its contents, but nevertheless felt that accessibility of the report should not be subject to judicial discretion.

Seven of the judges denigrated the usefulness of the report, claiming that, with the exception of the portion dealing with past criminal record, it was rarely if ever determinative of sentence in any way. Yet none of the judges who expressed this attitude thought that the defendant should be given the right to see the report. Those judges in the group who believed that defendant presently had, or should have, this right admitted the greatest level of reliance upon the report.

Perhaps the greatest resistance to mandatory disclosure resulted from the fear that once the report was made available to the defendant as a matter of right, the procedures by which, and the extent to which, the contents could be challenged would be formalized, thereby creating a procedure similar in length and intricacy to that governing the adjudication of the actual charge. Opinions of the judges as to what kind of hearing, if any, should be required on facts contained in the report were as varied as their opinions on the question of confidentiality. Suffice it to say that a substantial minority of the trial judges conceded that there are circumstances in which they might use information to shape a sentence and yet be unwilling to reveal the specific information and its source to the defendant. This situation suggests that a request for a presentence report would normally be part of a competent counsel's job, and that the denial of such a request would call for an argument based on the present case law supporting the right of access to the report. $^{30}$

69 The question of access to the presentence report has been extensively debated in the federal system. In 1944 a rule to allow access to the report was submitted to the Supreme Court by the Rules Advisory Committee. Proposed Fed. R. Crim. P. 32(c) (2), Report of the Advisory Committee on Rules of Crintnal Procedure 33 (1944). Even though the proposed level of access was to be subject to the discretion of the trial judge, the proposal stimulated vigorous opposition. See Hincks, In Opposition to Rule 34(c)(2), Proposed Federal Rales of Criminal Procedure, 8 FED. Prob. 3-9 (Oct.-Dec. 1944). The Supreme Court deleted the proposed rule before the statute was sent to Congress. In 1962 another rule was drafted calling only for disclosure of a summary of the materials contained in the report. This too was rejected.

In March 1964, the Committee on Rules of Practice and Procedure in its Second 


\section{Challenging the Contents of the Report}

If access to the report is granted, how can its contents be challenged? As with the issue of confidentiality, there are no statutes, judicial decisions, or rules of court defining procedures for challenging a presentence report. The two United States Supreme Court decisions discussed above in connection with the question of access to the report speak to the problem, but in a seemingly contradictory fashion. Speaking for the Court in Williams v. New York, Mr. Justice Black said of the information contained in the presentence report:

To deprive sentencing judges of this kind of information would undermine modern penological procedural policies that have been cautiously adopted throughout the nation after careful consideration and experimentation. We must recognize that most of the information now relied upon by judges to guide them in the intelligent imposition of sentences would be unavailable if information were restricted to that given in open court by witnesses subject to cross-examination. And the modern probation report draws on information concerning every aspect of a defendant's life. The type and extent of this information make totally impractical if not impossible open court testimony with cross-examination. Such a procedure could endlessly delay criminal administration in a retrial of collateral issues. ${ }^{40}$

Yet, Mr. Justice Black had joined in the Court's opinion in Tozensend v. Burke, ${ }^{41}$ decided one year earlier. There, Mr. Justice Jackson, referring to the use of misinformation by the sentencing judge, had noted:

Preliminary Draft of Proposed Amendments to Federal Rules of Criminal Procedure suggested wider access to the presentence report:

If the defendant is represented by counsel and so requests, the court before imposing sentence shall permit counsel for the defendant to read the report of the presentence investigation (from which the sources of confidential information may be excluded) and shall afford such counsel an opportunity to comment thereon. If the defendant is not represented by counsel and so requests, the court shall communicate, or have communicated, to the defendant the essential facts in the report of the presentence investigation (from which the sources of confidential information may be excluded) and shall afford the defendant an opportunity to comment thereon. Any material disclosed to the defendant or his counsel shall also be disclosed to the attorney for the government.

The present version of rule 32(c) (2) incorporates some of the 1964 recommendations, but still leaves the trial judge much discretion as to disclosure:

The court before imposing sentence may disclose to the defendant or his counsel all or part of the material contained in the report of the presentence investigation and afford an opportunity to the defendant or his counsel to comment thereon. Any material disclosed to the defendant or his counsel shall also be disclosed to the attorney for the government.

40337 U.S. 241, 249-50 (1949) (citation omitted).

41334 U.S. 736 (1948). 
Counsel, had any been present, would have been under a duty to prevent the court from proceeding on such false assumptions and perhaps under a duty to seek remedy elsewhere if they persisted. ${ }^{42}$

One might read Williams as merely saying that the original use of ex parte information by the sentencing judge is not a violation of due process when, as in Williams, there is no attempt by counsel to challenge the report, leaving open the question what due process might require if he does challenge the report. On the other hand, Townsend might be limited by the fact that the misinformation used in that case could have been corrected by the introduction of proper public records. $^{43}$ The present posture of the law is ambiguous and seems to afford scant support for those who would argue for any specific procedure, as a due process right, in challenging the contents of a presentence report.

The more immediate concern is with the procedures followed by the trial judges of the Philadelphia courts when the contents of a presentence report are challenged. An allied question is what norms the judges feel should guide them in this area. No one could envision, given the range of discretion the judges presently have in determining sentence after adjudication of guilt, ${ }^{44}$ what real advantage could be secured for the defendant by forcing a judge to follow certain procedures in relation to the use of the report that the judge would not otherwise have followed. Consequently, all of the judges questioned felt that the scope of a hearing on the information contained in the report should be left to the discretion of the trial judge.

The procedures that these judges would allow range from allowing the defendant or his counsel to make a statement to the court before sentence or comment specifically on the report or its summary, to allowing the writer of the report or his informants to be crossexamined on its contents. However, regardless of the outer limits of procedure that the individual judge would allow, 23 of them stated that the extent of the challenge allowed would depend upon how crucial the information being challenged was in his sentencing decision. Throughout the discussions on this point, considerable fear was expressed of any procedures that would waste judicial time. Allowing counsel great leeway in challenging information merely because it was in the judge's possession, without regard to the weight it was in fact given, made sense to no judge. When a judge talked of the extent of challenge he would allow, he was referring to a challenge to information that was consciously being used in determining sentence.

42 Id. at 740 (1948).

43 This hypothesis is somewhat discredited, however, by the reference to Tozensend in Mempa v. Rhay, 389 U.S. 128, 133 (1967), where the former decision is broadly construed. See text accompanying notes 67-69 infra.

44 Pa. Stat. ANN. tit. 61, § 331.25 (1964). 
The scope of challenge was smallest among that minority (4) who expressed doubts about the value of the information contained within the report, aside from past criminal record. These judges acknowledged that they would allow the investigation to be made and accept the report in those cases in which the defendant could be sentenced to two years or more, ${ }^{45}$ but insisted that the report carried little or no weight in passing sentence. The majority would allow counsel to present witnesses to support defendant's challenge or to impeach the source of challenged information, but would not cause the informants to be brought to court for cross-examination. The basis for this position was a feeling that, while counsel should be given wide latitude in supporting his attack on the report, putting the informants under the burden of coming to court and submitting to hostile examination would eventually curtail the flow of information.

Eight of the judges conceded that a situation might arise where, because of the extreme importance of some information in the report, they might cause the informant or the investigator to be brought into court to testify and face cross-examination. Their reasoning was that, to the defendant, disposition is the crucial element of the case, and if disposition turns on an issue outside the scope of indictment, the opportunity to be heard on that issue should approach that of the adjudicatory stage of the proceedings.

In many instances an ambivalent attitude towards this question of scope of challenge was apparent. Almost all of the judges expressed a wariness of further delay in criminal administration through challenges to the report, but they also felt that, so seldom did counsel challenge the contents of a report, the whole issue was not very important. In response to the question whether this did not indicate that the added delay in criminal administration would not be very great if broad challenges to the report were allowed, many judges replied that they feared the possibility that allowance of this leeway might promote frivolous challenges.

Assuming that the report is made available for challenge and evidence is heard on both sides, the final question is how the court should then proceed. The question is not really one of burden of proof in the sense of creating a standard subject to review, since the system is one in which the entire proceeding is presently within the court's discretion. The real question is how the trial judge feels he should view information challenged in the hearing. Those judges who allowed the narrowest challenge claimed that they most easily disregarded challenged information. In other words, those judges who merely allowed the defendants to make an assertion in court before sentence tended to put the challenged information in doubt merely on the basis of an unsupported contrary statement by the defendant. This

45 See PA. Stat. Ann. tit. 61, §331.25 (1964). 
formulation may be illustrated by the following example. If the report indicated drunken and abusive conduct towards the defendant's family, and if this was important enough to point out to the defendant at sentencing, his unsupported statement that he was a sober and charming father and husband would put the issue in equilibrium. The judges in this category claimed that they would then think about disposition as if they knew nothing at all about the man's conduct towards his family. Aside from the problem whether it is psychologically possible to ignore a factor, presumably thought crucial, merely because one has heard something contrary on the point, is this a sensible way to proceed? The issue does not become less relevant because in doubt. Should it be discarded so quickly? The claim that challenged information is so readily ignored may merely be a rationalization for not allowing more than an unsupported denial.

Those judges who allowed a fuller hearing on the challenged information admitted that they were usually persuaded by one side or the other. These judges claimed that they tried to shape the sentence as if they had no information at all on the point only when the weight of the evidence on each side was equal, not merely because there was doubt. When asked whether the state should have the burden of proof on a crucial issue, much as in the trial, the general reaction was that, after exposure to the contentions of the report and defendant's challenge, the judges would act on the information they believed.

Finally, of these 3 judges who would allow the challenge to go as far as calling the author of the report, one judge would limit examination to the method of gathering and the sources of information in the report, but would not allow any questions relating to the officer's recommendations.

\section{B. Other Elements Before the Court}

A view of the presentence report as a critical element, and the consequent judgment that the defense lawyer must be aware of its contents because of their influence upon the sentencing judge, makes relevant the question what other elements are before the court, and as such possibly determinative of the defendant's chances for probation.

Two other elements that loom significant in the choice between incarceration and probation, and that were mentioned by every judge, are (1) the nature of the crime, and (2) pressures brought to bear from external sources, particularly the press.

\section{Nature of the Crime}

The statute empowering trial courts to grant probation is broad, excepting only first degree murder. Yet the nature of the crime has a definite influence upon the sentencing judge. For example, not one of the judges interviewed thought it likely that he would ever 
grant probation to a person convicted of any crime of violence against a police officer.

The reasons given for sensitivity to the nature of the crime in making the choice between probation and incarceration fall roughly into two categories. The first encompasses those factors that indicate to a judge the probable results of an ill-advised decision to grant probation. A question is framed along these lines: What does the nature of this crime reveal about how much, and what kind of danger the community will be exposed to if I make an error in allowing this offender the relative freedom of probation? In answering this question, every judge made some distinction between those guilty of crimes of violence and those guilty of property crimes, and every judge was more willing to risk an error with an offender whose total picture (nature of the crime and background as disclosed by the presentence report) showed a lack or low level of violence. Where the crime charged was one of violence, the judges would look for some element which might isolate the act from a general pattern. Such an element might be a provocation that, although not a defense to the charge, might nevertheless affect a prognosis of future acts.

While a higher degree of specificity might be of interest and value, no judge was willing to respond to more narrowly framed questions. For example, no judge would speculate on the relative chances for probation of two offenders with like presentence report recommendations, one of whom was a first-time violent offender, the other of whom was a two-time property offender. The only conclusion that can be responsibly drawn is that the violent offender has less of a chance for probation than the property offender because of the judge's sensitivity to the danger to the community that may follow an error in judgment. ${ }^{46}$

The second category encompasses those factors that relate to the effect of a given decision upon the offender's immediate community. The concern expressed here is not merely with the deterrent value of punishment upon the community at large, but also with the effect upon the offender's intimates who know the crime of which he is guilty, and who will know that he is either back on the streets with them or in prison. This factor is operative when the judge feels that he has before him an offender whose conduct, while criminal, is neither exceptional nor frowned upon among the offender's associates. Stated more bluntly, the offender who comes from a background that the judge feels upholds societal values has a better chance of returning to that background on probation following the commission of a crime than the offender coming from a group among whom the offense

46 Interestingly enough, little mention was made by the judges of the possible adverse effects (except on the offender himself) of an erroneous decision not to grant probation. 
charged is no great deviation from that group's behavior. As between offenders $A$ and $B$, both charged with assault and battery growing out of a barroom brawl, offender $A$, all other things being equal, has a better chance to be placed on probation if barroom brawls are exceptional happenings in his "immediate community" than offender $B$, who comes from a neighborhood where the Friday night brawl is a regular occurrence and a continuing problem for the police and minor judiciary.

There are some practices, however, that the judges are so anxious to forestall that they will, absent some very special circumstances, want to remove the offender from his neighborhood, no matter what the societal values of that neighborhood. The offense of this type most often mentioned was assaulting a police officer.

\section{External Pressures}

The second element discussed by the judges concerned pressures not necessarily related to either the particular offender or his offense. Two sets of problems must be distinguished: those produced by groups, such as the mass media, that shape but do not necessarily reflect public opinion, and those arising from the pressures brought to bear by public opinion itself. Of the former, the only source generally discussed was the local press. Each of the judges was asked two questions leading into a more general discussion. The first was whether the judge in sentencing was ever influenced by what the newspapers might be saying either about the particular case before him or about the wisdom of probation in general. The second was whether they believed that their brother judges were ever influenced by pressure from the press. Eighteen of the judges answered the first question negatively and the second affirmatively. Two stated that they could not make an accurate self-evaluation and refused to comment on the second question. Finally, one judge, who expressed a belief that the press accurately reflected public opinion in this area, admitted that the press did affect his sentencing and, he believed, properly so.

Except by this single judge, however, the press was viewed as a director of public opinion rather than as a reflection of it. In this light, no matter what the judge's opinions were as to the actual influence the press had in making dispositional choices, that influence was seen as improper and invidious. The judges unanimously believed that probational dispositions had received a very unfavorable press in Philadelphia. The pressures under discussion, however, were those generated by a level of comment below that which would furnish a basis for appeal on the ground of prejudicial pretrial publicity. ${ }^{47}$ No judge had any suggestion as to how these pressures could be neutralized or mitigated, except by mounting a public educational

47 See, e.g., Sheppard v. Maxwell, 384 U.S. 333 (1966). 
campaign on the subject of probation and the treatment of offenders. None felt that funds for such a project would be made available.

A much more difficult question is the effect of public opinion itself. : Of the judges questioned on this point, most said they felt that the public generally had no opinions as to the proper disposition of any particular offender or, if it did have such opinions, lacked the means to articulate them. With the exception of 4 judges, the prevailing attitude was that even if public opinion were ascertainable, it would not be a proper factor in the sentencing of any particular defendant. The consensus was that if the electorate, informed or otherwise, wished to change the ratio between probation and imprisonment in criminal dispositions, or wished to limit or otherwise affect the trial judge's discretion, the legislature and not the judiciary should recognize and respond to their desires. Four of the judges (including the judge who acknowledged the influence upon himself of the press in the sentencing process and affirmed the propriety of such influence) said that the public's desires, if ascertainable, were a proper factor in determining sentence:

One other source of pressure, which 6 judges mentioned without questioning, was the district attorney's office. A story told by one judge is significant in that it demonstrates both how this pressure is brought to bear and how the judiciary might react to it. The instance involved a trial, without jury, on a charge of statutory rape. In hearing the case, the judge came to two conclusions: first, that the defendant had committed the offense, and second, that because of other factors the accused did not deserve imprisonment. A presentence report telling of the defendant's family and gainful employment further confirmed the judge's belief that probation was the proper disposition. In an informal meeting with an Assistant District Attorney prior to sentencing, the judge was informed that the District Attorney was very anxious to have convicted sex offenders sentenced to prison rather than granted probation. The judge proceeded to sentence the defendant to a term of probation and then found himself condemned in the press as soft on sex offenders. The judge was convinced that the story had been fed to the press from the district attorney's office. While he thought that probation was the best disposition of the case, the judge said that in a similar situation in the future he would be strongly tempted to find the defendant not guilty of the charge and avoid being attacked for his lenience with a convicted defendant.

\section{Individual Opinions as Determinative}

In attempting to assess the factors that determine whether or not an offender will be given probation, the focus has been on elements (presentence report, nature of the offense, pressures from the mass media and other institutions) that most often relate to the particular 
case. $^{48} \mathrm{~A}$ catalogue of determinants, however, is incomplete if it does not attempt to deal with the attitudes of the judiciary toward sentencing. These attitudes, whether fully capable of articulation or not; place a gloss on all the other elements. The inquiry here does not: attempt to answer the questions about the actual benefits and risks of probation as opposed to imprisonment, nor does it attempt to suggest a more rational process (if one exists) for determining: the proper disposition. The question is merely what the judiciary believes are the benefits and risks of probation, and how these beliefs are likely to affect the determination that a particular judge,'- or 'id particular group of judges, is likely to make.

If the factors dealt with above are viewed as individual hurdles that stand between a guilty defendant and a grant of probätioni, 'a: valuable method for inquiry into judicial attitudes is to postulate $\ddot{a}$ model in which all of these factors are positive for probation, 'and then: to ask under what circumstances an offender might still be sentenced to prison.

The presentation of the model varied with each particular interview, but every judge was asked if he felt that probation was'a better disposition than imprisonment from a rehabilitative standpoint: All: answered this question affirmatively, with some reservations 'when certain institutional facilities were compared to specialized probationary' supervision for certain types of drug and sex offenses.

Given a belief that the offender has a better chance for rehabilitation on probation than in prison and a prognosis that does not indicate danger to the public from future activity, the next question was what considerations might still lead to a prison sentence as opposed tơ probation.

In response to this question, the effect of the frequency! of probation as opposed to imprisonment relative to the larger community, as opposed to the effect of a specific sentence on the "immediate community," was discussed. ${ }^{49}$ The single element (mentioned by 19 of the judges) that might indicate a sentence of confinement, despite the absence of any future threat to the community and the existence of a greater opportunity for rehabilitation with probation, was deterrence. In this context, deterrence referred to the community at large, rather than to the particular offender.

Although deterrence was taken into consideration by the great: majority of the judges, there were great differences of opinion regard: ing what types of crimes are deterred by the nature of the punishment for their commission and what is the effective level of the deterrence. While all judges questioned agreed that there exists in the community

48 Pressures from outside sources may not, however, relate to the particular case. See pp. 339-40 supra.

40 See pp. 337-39 sipra. 
a far greater temptation to commit certain types of crimes (for example, tax avoidance and traffic violations) than any other types of offenses, property or personal, all agreed that penalties in the form of fines would have sufficient deterrent capability. ${ }^{50}$

Eighteen of the 25 judges interviewed believed that if offenders without recidivistic tendencies were always granted probation for a first offense, the incidence of certain types of violent crime would rise. Most often mentioned were crimes of violence among family members and acquaintances. The judges' prediction probably rests on a belief that punishment of this type of offender has a substantial deterrent effect on others who have a tendency to commit such crimes.

These opinions indicate that a great majority of the trial judges interviewed feel that the decision to grant probation involves more than the simple determination that society will be protected from the individual offender and that the offender's chances for rehabilitation are better if he is put on probation. For these judges, the protection of society from its own dangerous impulses is a viable consideration in determining the disposition of a particular offender.

A minority of judges stated that they would grant probation upon finding that the defendant would be no threat to society if at liberty, and that he had a better chance for rehabilitation if on probation. These judges based their conclusion on their doubt of the deterrent value of punishment in general rather than on a repugnance for sentencing an individual on the basis of considerations going beyond his particular circumstances.

Two values other than deterrence were mentioned: punishment as lending affirmation to certain societal values ${ }^{51}$ and punishment as an element of justice for a wrong. Four judges who talked of the need to punish the commission of certain offenses to reinforce societal values stressed that the criminal law is not only a means by which the state deals with those individuals who break its laws, but is also a means by which society asserts that certain conduct is wrong. This view is still utilitarian, but focuses on an intermediate opinion as to what might happen if the ratio between imprisonment and probation were to shift sharply toward the latter. It fears in such a shift not only the possible loss of the deterrent value of punishment, but also the possibility that support given to the moral values of society, enforced by the punishment of those who transgress those values, will be greatly lessened. The view is that if the state responds to the doing of certain acts with sanctions based only on its need to protect itself

50 There was a feeling, therefore, that the imposition of a prison sentence for corporate executives found guilty of violating criminal provisions of the federal antitrust law, where some method could assure that the burden of the fine would be borne by defendants as opposed to the corporation, involved some value other than deterrence.

51 That is, the tendency of punishment for an act to support and reinforce the moral judgment of society on the act. 
from the offender and on the offender's own rehabilitative needs, then the belief that the act is wrong in a moral sense will be undermined.

Of course, the extent to which such a view weighs against probation is difficult to assess beyond stating that it was articulated by only 4 of the judges interviewed. It can only be surmised that such a belief, when held by the sentencing judge, must place another hurdle between the offender and probation.

Finally, 2 judges expressed a Kantian view of the function of punishment. ${ }^{52}$ These judges talked of punishment not in utilitarian terms, but only as a means of redressing a wrong, of creating an equivalent, as doing justice. They both stated that their use of probation only responded to the much higher economic cost to society whenever imprisonment is imposed.

\section{Revocation of Probation}

Any attempt to understand probation as a disposition of convicted offenders must deal not only with how probation is granted, but also with how it is revoked. Even assuming that no convicted offender has a right to probation, questions remain concerning the procedures that the state must follow before it can revoke probation and sentence the probationer to prison. A second question is what, in fact, are the procedures generally followed and the considerations taken into account by the trial judge in a revocation proceeding.

The Pennsylvania statute controlling revocation of probation provides:

Whenever a person placed on probation, as aforesaid, shall violate the terms of his or her probation, he or she shall be subject to arrest in the same manner as in the case of an escaped convict; and shall be brought before the court which released him or her on probation, which court may thereupon pronounce upon such defendant such sentence as may be prescribed by law, to begin at such time as the court may direct. ${ }^{53}$

The meagre case law interpreting this statute indicates that the term "brought before the court" implies a judicial determination of whether any terms of probation have been violated, as opposed to a mere redetermination of the probationer's suitability for probation. ${ }^{54}$ It has also been held, however, that the procedures followed at a revocation hearing need not conform to those used in a trial, nor need

52 See J. Michaet \& H. Wechsler, Criminal Law and Its Administration 6-17 (1st ed. 1940).

53 Pa. Stat. Ann. tit. 19, $\$ 1055$ (1964).

54 Commonwealth v. Fox, 69 Pa. Super. 456 (1918). 
the evidence used be restricted to that which would be admissible for an adjudication of guilt or innocence on a criminal charge. ${ }^{55}$

In 1964, the Pennsylvania Supreme Court, in Remeriez $v$. Maroney, ${ }^{56}$ held that a probationer had a right to counsel at a revocation proceeding and that the state had a duty to supply counsel, if requested, to an indigent probationer since this was a critical stage in the criminal process under the rationale of Gideon $v$. Wainwright. ${ }^{57}$ However, the critical nature and, hence, the role of the lawyer; was seen in relation to the dispositional nature of the hearing as opposed to the fact-finding element. The United States Supreme Court in Mempa v. Rhay ${ }^{58}$ extended the right to counsel to revocation.proceedings in all states, but the scope of the decision is ambiguous. ${ }^{59}$. In summary, present Pennsylvania law clearly seems to impose three requirements for revocation of probation: (1) the probationer must be brought before the court, (2) he has the right to be represented by counsel if he desires, and ( 3 ) the court must hold a hearing to determine whether any conditions of probation have been violated.

There are otherwise very few grounds upon which to attack a revocation proceeding. In Burns $v$. United States, ${ }^{60}$ generally cited by those who deny the applicability of the norms of procedural due process to probation revocation proceedings, the Supreme Court noted that due process did not entitle a probationer to any specific procedures at the revocation hearing, but merely required that he be treated fairly and not be made the victim of whim and caprice. Indeed, the Supreme Court there held that a refusal to hear any evidence at all from the probationer seeking to explain the actions with which he was charged was not an abuse of judicial discretion. If Burns is still good law, the prospects for a due process argument do not seem promising. ${ }^{61}$ Despite the fact that a very extensive body of constitutional law of criminal procedure has been developed, touching every phase of the criminal process up to the point of determination of guilt or innocence, counsel for a probationer will presently have to rely strongly on equitable arguments to the sentencing judge if a fair hearing seems difficult to obtain.

55 Commonwealth ex rel. Remeriez v. Maroney, $415 \mathrm{~Pa} .534,204$ A.2d 450 (1964); Commonwealth v. Milk, 198 Pa. Super. 442, 181 A.2d 702 (1962). But cf. Commonwealth v. Elias, $394 \mathrm{~Pa}$. 639, 149 A.2d 53 (1959); Commonwealth v. Duff, $201 \mathrm{~Pa}$. Super. 387, 192 A.2d 258 (1963), rev'd on other grounds, 414 Pa. 471,200 A.2d 773 (1964).

$56415 \mathrm{~Pa} .534,204$ A.2d 450 (1964).

57372 U.S. 335 (1963).

58389 U.S. 128 (1967).

59 See text accompanying notes 66-72 infra.

60287 U.S. 216 (1932).

61 The strength of Burns today is questionable: concepts of due process have evolved since 1932, and the Supreme Court in Mempa avoided contradiction with Burns by avoiding mention of the case. In fact, the last mention of Burns in the Supreme Court was in 1954. Sacher v. Association of the Bar, 347 U.S. 388, 394 (1954) (Reed, J., dissenting). Cf. Rose v. Haskins, 388 F.2d 91, 98 n.3 (6th Cir. 1968) (Celebrezze, J., dissenting); Hyser v. Reed, 318 F.2d 225 (D.C. Cir. 1963). 
The view of adjudication of guilt as the Rubicon of the criminal process finds its strongest support in an opinion written by $\mathrm{Mr}$. Justice Cardozo in Escoe v. Zerbst, ${ }^{62}$ in which the Court construed a federal probation statute as requiring that the probationer be given a hearing before revocation could occur. The opinion was careful to state that since probation is an act of judicial grace, the right to a hearing before it is revoked has no constitutional basis and can only be derived from a statutory grant.

In this holding we do not accept the petitioner's contention that the privilege has a basis in the Constitution, apart from any statute. Probation or suspension of sentence comes as an act of grace to one convicted of a crime, and may be coupled with such conditions in respect of its duration as Congress may impose. ${ }^{63}$

Such a view of a probationer's constitutional rights might be further supported by looking upon probation as a contract between the state and the defendant that the latter is free to either accept or reject. The terms of such a "contract" include a provision that revocation of probation will be controlled by the state. The problem with this analysis is that it assumes that, even if the revocation of probation would be limited by constitutional considerations of due process, acceptance of probation would constitute a waiver of such rights. Of course, this would make any such constitutional consideration a nullity, except in the rare case where probation is "forced" upon the offender. Since the convicted defendant's alternative to acceptance is the immediate imposition of sentence, it would hardly seem that the acceptance of probation would constitute a voluntary waiver, as the Supreme Court now interprets that phrase in determining whether a constitutional right has been effectively waived. ${ }^{64}$

A more subtle and convincing argument in support of the notion that the norms of due process for adjudication of guilt and revocation of probation are very different is the view that probation is not really a grant of liberty, but merely a custodial decision as to the manner in which an already imposed sentence will be carried out. Probation is thus viewed not as freeing the defendant from service of sentence, but merely as a device by which the walls of confinement are extended to allow the offender to serve his sentence in the community, still

62295 U.S. 490 (1935).

63 Id. at 492. Contra, Fleenor v. Hammond, 116 F.2d 982 (6th Cir. 1941), which held that a grant of pardon, even though conditional, could not be summarily revoked, and that due process required that a finding be made that some condition of the grant had been broken. It relies on the language of Escoe, but badly distorts its holding; the right to a hearing was in that case based upon a statutory mandate rather than a constitutional requirement. (1968).

64 Cf. Note, Another Look at Unconstitutional Conditions, 117 U. PA. L. Rev. 144 
subject to the control of the trial court, just as he would be subject to the control of the prison authorities if he were serving his sentence within the prison walls.

This argument, however, cannot obliterate the fact that most communities differ substantially from prisons, and that one's condition should not be so drastically changed by the state without substantial safeguards. Second, such a view of probation is inconsistent with the relevant statute, which does not require time spent on probation to be considered as time served under sentence, and allows the court to impose any sentence that could have been imposed originally. ${ }^{65}$

Also supporting the argument for informal or summary revocation proceedings is the contention that, if these proceedings are subject to the rules required for criminal trials, with all the concomitant bases for appeal, the ultimate result will be fewer probationary dispositions. This argument may have some merit, but its force is questionable. It seems to be based on an assumption that the grant of probation serves no social interests recognized by sentencing judges.

The Supreme Court's recent decision in Mempa v. Rhay ${ }^{66}$ may herald the development of due process protections for defendants on probation. The Court there held that due process requires the appointment of counsel in proceedings to revoke probation. A possible implication of this right to counsel is the right to procedural due process at the proceeding. The opinion in Mempa is ambiguous, but there is some indication that a lawyer's presence was viewed as a critical aid to the probationer in the fact-finding process by which it is determined that there has (or has not) been a violation of the conditions of probation. The Court noted that Townsend $v$. Burke ${ }^{67}$ had held that "the absence of counsel during sentencing . . . coupled with 'assumptions concerning his criminal record which were materially untrue' deprived the defendant . . . of due process." 68 Although the scope of Townsend has itself caused considerable difference of opinion, ${ }^{69}$ it is perhaps significant that the Court in $M e m p a$ quoted language from the case that most strongly suggests a role for counsel in the fact-finding process and the applicability of norms of procedural due process in order to ascertain the truth. Further, the Court's statement of the

65 Pa. Stat. ANn. tit. 19, $\$ 1055$ (1964). The present system, which suspends imposition of sentence until revocation of probation and gives no credit for time spent on probation, seems to view probation as liberty and not merely as a particular mode of discharging a penal obligation. Perhaps much of the constitutional objection to summary revocation procedures could be satisfied by imposing and then suspending sentence prior to the grant of probation and, in the event of revocation, giving formal credit for the time spent on probation. Under such a system, probation could more easily be conceptualized as a "floating jail."

66389 U.S. 128 (1967).

67334 U.S. 736 (1948).

68389 U.S. at 133.

69 See text accompanying notes $22-34$ supra. 
facts in Mempa places emphasis on several of the factors most often mentioned in connection with procedural due process. ${ }^{70}$

On the other hand, much of the opinion seems to suggest that the lawyer's presence was viewed as essential only because of his function as an advocate in influencing the sentencing judge's recommendations to the parole board, and in order to safeguard certain legal rights of the probationer. $^{71}$ The Court noted, for example, that counsel might inform an ignorant probationer of his right to petition the trial court for permission to withdraw the guilty plea upon which the sentence of probation was originally predicated. ${ }^{72}$ The Court may have viewed these as the chief or only roles for counsel in such proceedings. It should be remembered, however, that in $M e m p a$ there was no disputed issue of fact, and revocation itself was not at issue. At the very least, Mempa represents a substantial change in the law, and is in no way inconsistent with an argument that procedural due process is constitutionally required at revocation hearings.

Absent a constitutional command for specific procedures, however, perhaps the most important factor is the interests the trial judge believes are being served by probationary dispositions. Choices of desirable fact-finding procedures at the revocation hearing must be made in light of an understanding of exactly what jeopardy the probationer is in subsequent to a finding of a probation violation. The relevant Pennsylvania statute ${ }^{73}$ indicates that the trial judge originally has the alternatives, after adjudication of guilt, of (1) sentencing and executing sentence against a guilty defendant, (2) sentencing and suspending execution of sentence, or (3) suspending sentence and assigning the defendant to a definite term of probation. ${ }^{74}$ Since a probation order suspends sentence, the probationer who is later found guilty of a violation will be sentenced by a judge not bound by a previously determined sentence, the execution of which was suspended. The judge will now be free to, and very probably will, take the violation into consideration when passing sentence. Of course, the sentence imposed after revocation cannot exceed the statutory limit for the crime charged, but the sentence received after not only a finding of guilt, but also of a violation of probation, may well be more than that which might have been imposed originally after a

70 A probation officer testified without cross-examination that according to his information petitioner had been involved in the burglary ....

389 U.S. at 131 (emphasis added).

At the hearing a probation officer presented hearsay testimony to the effect that petitioner had committed the acts [resulting in revocation of his probation].

Id. at 132 (emphasis added).

71 See, e.g., id. at 135: "the necessity for the aid of counsel in marshalling the facts, introducing evidence of mitigating circumstances and in general aiding and assisting the defendant to present his case as to sentence is apparent."

72 Id. at $135-36$.

73 PA. Stat. ANn. tit. 61, §331.25 (1964).

74 But see Commonwealth v. Duff, $201 \mathrm{~Pa}$. Super. 387, 192 A.2d 258 (1963). 
finding of guilt. The probationer, however, receives some benefit from the fact that until completion of the fact-finding portion of the revocation hearing no sentence has been imposed. He is still free to move for a new trial or otherwise to show cause why judgment should not be pronounced, just as if there had not been the period of probation between the time of trial and the revocation hearing.

It might be argued that, since the trial judge is making a decision on sentence for the first time at the revocation hearing and is not bound by a previously determined sentence, the procedures surrounding the fact-finding portion of the revocation hearing should be more formalized along the lines of those used in the original trial of the issue of guilt or innocence of the crime charged.

The probationer may not, however, really be hurt by the judge's consideration of the probation violation in shaping sentence, since a judge is free to use all types of information coming to him free of the screening of the trial process in shaping a sentence subsequent to the finding of guilt. Even the information relied on in a presentence report is no more fully developed or certain of accuracy than that which is brought out in even the most informal of revocation hearings. Since this is so, it is probably proper-and indeed the rationale of the legislature in creating such a scheme may be-for the trial judge to take into consideration not only the probation violation, but also any other information that has come to him since the original imposition of probation. It can also be argued that the additional jeopardy may have a further deterrent effect upon a probationer who will realize that the severity of sentence imposed subsequent to a probation violation will reflect that violation in addition to the commission of the crime.

Analysis of the jeopardy of revocation must also include an understanding of how the revocation process is triggered. Violations of probation fall into two categories: "direct" and "technical." 75 "Direct" violations include the commission of any crime subsequent to the original grant of probation ${ }^{76}$ or violation of any special condition of probation-for example, a prohibition against association with a certain individual who is viewed as a bad influence. "Technical" violations include failure to adhere to any routine condition of probation, such as reporting to the probation officer. ${ }^{77}$

When a probationer is arrested for a new offense, the probation officer is notified and a detainer is issued to prevent release on bail. The revocation hearing is generally delayed until after trial or other disposition of the current charge. This postponement raises additional problems for the probationer. Where he has been found or has

75 Interview with Frederick Downs, Jr,, Chief Probation Officer, Court of Quarter Sessions, Philadelphia, August 21, 1968.

76 Interviezs of $J_{u d g e s .}$

77 Id. 
pleaded guilty, the question of procedures for fact-finding at the revocation hearing are moot: the court in either case can simply rely on the conviction. However, a dismissal or a finding of not guilty does not remove the possibility of revocation of probation. Such a disposition would only bind the court on the question of commission of the crime. The court is not foreclosed from finding other facts surrounding the arrest which themselves often constitute a technical or even a direct violation.

Among the trial judges of Philadelphia the predominant sentiment was against the creation of a law of procedure surrounding the revocation of probation. While Mempa v. Rhay ${ }^{78}$ had not been handed down at the time of the interviews, the Pennsylvania Supreme Court in Remeriez $v$. Maroney ${ }^{70}$ had mandated counsel at revocation hearings. The existing procedural requirements that framed these inquiries were, therefore, that prior to revocation of probation the probationer had to be brought before the court for a hearing, that he had a right to be represented by counsel, and that there had to be a finding based on "some evidence" that the probationer had violated some condition of probation. ${ }^{80}$

In no case did a judge's idea of what procedures should be required before revocation could occur correspond to what he said were his actual procedures in a revocation hearing. And in all instances (among that majority of judges who were against the development of further procedural requirements for revocation) the idea of what procedures were probably best differed from the idea of what procedures a probationer should have as a matter of right. The reason most often given for these disparities was a fear that the development of procedural requirements would open up a whole new area of appeal, further burdening the judiciary. A second and less pressing concern was the belief that while certain procedures might be appropriate for most revocation hearings, the whole area was one that was best left flexible, leaving broad discretion to the trial judge. It was assumed that, as the right to a hearing had been so minimally defined by state case law, ${ }^{81}$ the right to counsel would not open any substantial area of appeal, since such a right would not carry any implications that would in themselves widen procedural requirements. ${ }^{82}$

To suggestions for a clarification of the law concerning the nature of notice to which a probationer is entitled, the response was that formalizing such requirements would lead to appeals based on any variance between the violation charged and the violation proved, at least in those instances where the revocation was based on a technical

78389 U.S. 128 (1967).

70415 Pa. 534, 204 A.2d 450 (1964).

80 Commonwealth v. Fox, $69 \mathrm{~Pa}$. Super. 456 (1918).

81 See cases cited notes 54-55 supra.

82 Interviezes of Judges. 
as opposed to a direct violation. Even though the occasion for revocation is only the violation of a condition, the judges felt that the revocation hearing was an appropriate time for a general review of the probationer's progress.

In the area of evidentiary rules, the judges felt that, if there developed a tendency to duplicate the requirements of the original adjudication of the crime, there would be a proliferation of appeals from revocation hearings based on evidentiary rulings by the judge. The majority thought that granting the probationer a right of crossexamination would lead to the development of a correlative right of access to the files of his probation officer. Such an eventuality was viewed negatively. ${ }^{83}$

Strangely enough, the same judges who raised objections to a more formalized procedure for revocation, based on the possible burdens upon criminal administration, also claimed that the area of possible controversy was not very wide. In underscoring this point, two judges stated that they could foresee no conditions under which they would revoke probation for a "technical" violation. Since a conviction for a subsequent offense would conclude the issue of revocation for an alleged "direct" violation, these judges thought that the question of procedural rights at a revocation hearing was academic. While only these two judges stated that they never revoked probation for a technical violation, the balance of the interviewed sample also indicated that such revocation was rare unless urged by the probation department itself. ${ }^{84}$

According to the judges, even in those cases where probation is revoked because of a technical violation, it is rare for a factual issue to be raised. All of the judges indicated that when a factual issue is raised, they would go beyond what is procedurally required to enable the probationer to effectively refute the charge. There was complete agreement that the defendant would be allowed to present any evidence and witnesses he desired in his own behalf. A divergence, however, developed on the question of confrontation, and on the subordinate

83 The suggestion that granting a right to cross-examine would then open up the problem of access to certain probation department files was made by a judge in one of the first interviews conducted. The judge mentioned the case of Hencks v. United States, 353 U.S. 657 (1957). In that case, however, the Supreme Court directed access to files under their supervisory power, rather than by saying that such right was mandated by right of confrontation. In confronting the judges with this suggestion in later interviews, 14 out of 18 questioned felt that a right to cross-examine probation officers would lead to requirements that certain department files be made available to counsel for the probationer.

84 Interviezes of Jtudges.

In some cases, however, this may be misleading. Probation may be revoked for an alleged direct violation (commission of a crime) of which the probationer could not have been convicted because, for example, the only evidence against him was an unconstitutionally coerced confession. If the rationale of the exclusionary rule applies to revocation hearings, such results could often be justified only as revocation for a technical violation that may come to light at the same time, e.g., consorting with an alleged accomplice. 
questions of cross-examination and accessibility of records. Only 2 judges would command the production of pertinent probation department files. Only 10 judges would require a probation officer to submit to cross-examination in all cases of factual controversy. None would exclude hearsay evidence from their consideration. Those judges (all but 2 of those interviewed) who would not require the production of probation department files were asked if they would feel differently if a procedure were developed that first required an in camera inspection by the judge whereby any irrelevant information, or any information that it might be unwise to reveal to the defendant, would be withheld. Even with this screening system, these judges indicated that they would still oppose a formal requirement of production. $^{85}$

Only 3 judges favorably anticipated the development of a law of procedure for revocation of probation. Their main argument was based on the assumption also made by those who opposed such development. They reasoned that, since the occasion for factual controversy was so infrequent, the formalization of these hearings would neither burden the judiciary with appeals nor cause significant delay. On the other hand, they viewed the revocation hearing as the most crucial stage in the ultimate disposition of a convicted defendant already on probation. Since the law requires a violation of conditions before he can lose his liberty, ${ }^{86}$ these judges felt that the probationer's position warranted as scrupulous a fact-finding procedure as that surrounding the original trial. One judge went even further and argued that the state's burden should not be merely to establish some evidence of a violation, but to establish the fact of a violation beyond a reasonable doubt. The other 2 judges in this group still saw the state's burden only as establishing some evidence. They saw the utility of this standard to be to foreclose the possibility that any appeals from the sentence would be based upon the court's factual determination.

\section{ConCLUSION}

Any analysis of the desirability of probation as a treatment for convicted criminals must attempt to consider the relative economic costs of probation and incarceration. The President's Crime Commission has estimated the cost of incarceration to be approximately ten times that of probation supervision. ${ }^{87}$ That figure, however, fails to consider many other relevant factors. Any quantitatively correct estimate of the costs of imprisonment would have to take into account

85 Interviezus of Judges.

86 Commonwealth v. Fox, $69 \mathrm{~Pa}$. Super. 456 (1918).

37 President's CoMmission on LAW Enforcenent and AdMinistration of Justice, Task Force on the Administration of Justice, Task Force Report: The CourTs 15 (1967). The Commission estimated the yearly cost of probation supervision at $\$ 200$ and the yearly cost of imprisonment at $\$ 2,000$. 
not only the direct costs, but also indirect costs such as welfare payments to an offender's dependent family. Conversely, the cost of probation cannot accurately be judged if the cost to the community of crimes committed by probationers is not included. Even if it were possible to isolate all of the proper elements, it might yet be impossible to formulate a workable calculus. For example, the problem of estimating the "cost" of crime is immense, and even if such a figure could be ascertained, it would have to be discounted by those future criminal acts which the offender would have committed even had he been incarcerated. ${ }^{88}$

Even if one assumes, as do the trial judges, that probation places a much lighter financial burden on the community than does incarceration, ${ }^{8 \theta}$ the more fundamental question remains as to what goal or goals probation serves. As stated above, the most frequently cited purpose of incarceration is deterrence, ${ }^{90}$ even though none of the judges interviewed claimed to know in what degree and in what types of crimes this goal is served.91 Deterrence is first and most often mentioned as a goal probably because it is the most rational of hopes that society has for the punishment of offenders. ${ }^{92}$ At the farthest remove is the desire for retribution. Although all of the judges to some degree disapproved of the retributive element in sentencing, no judge would say that, even after being satisfied that the offender offered no future threat to society and that the crime was of a sort from which society need not be deterred, ${ }^{93}$ he would in all such cases impose probation instead of imprisonment. Since the absence of possible future danger and of the need for deterrence will not alone necessarily indicate probation, it is reasonable to assume that the retributive element does indeed play a significant role in sentencing decisions, whether because the judge personally thinks it proper or because he is responding to what he perceives to be the community desire. By and large, however, although the relevant goals in the treatment of offenders are known, the extent to which such goals are in fact served is more in doubt. What is suggested below, therefore, focuses not on when probation should be used but on what procedures should accompany its use.

88 On the other side would then appear the cost of any crimes he would commit if incarcerated but not if on probation.

89 Interviezes of Judges. The question of relative costs was put to all 25 judges interviewed. All believed that it cost the state less to put a man on probation than in jail.

90 See text accompanying notes $46,49-50$ supra.

91 It is not suggested here that the judges made no assumptions about deterrence. Indeed, all judges questioned assumed some deterrent was posed by the threat of incarceration.

92 See J. Michael \& H. Wechsler, Criminal Law and Irs Administration 6-17 (1st ed. 1940).

93 By a crime from which society need not be deterred is meant a crime that is probably more strongly deterred by other social forces than by criminal sanctionse.g., deviant sexual behavior. The hypothetical used here was structured on the case of Commonwealth v. Vivien, $208 \mathrm{~Pa}$. Super. 330, 222 A.2d 739 (1966). 
As a starting point, the presentence report should be made available to convicted defendants as a matter of right. This recommendation is founded not only with the realization that substantial disclosure may be constitutionally compelled, ${ }^{94}$ but also on the belief that the person to be sentenced should to the fullest possible extent understand the basis upon which his punishment is determined. Both actual and apparent rationality in the sentencing process are important to the achievement of several goals.

As has been mentioned, "deterrence" as a goal of penal sanctions can be accomplished in either of two ways. First, the particular defendant can learn from his punishment and hopefully be induced to adjust his future behavior. Second, the punishment can serve as an example to other would-be violators of the law. Revealed rationality in sentencing will be crucial in either case. In the most mundane sense, a convicted person cannot "learn" from a punishment, the reasons for which are hidden from view, and his sentence can be most effective as an example to others only when its bases are revealed. It may be argued that there is little public or individual sensitivity to factors in sentencing other than the fact of guilt, and, hence, that disclosure of these more sophisticated sociological and psychological factors is neither necessary nor even helpful. However, the same criticism can be levelled generally at deterrence as a goal of the criminal law, and so long as such a goal is accepted, disclosure of the determinants of the sentencing decision will be a valuable aid in its achievement. In terms of the rehabilitation of convicted criminals, communicated rationality in sentencing would seem important. The attitude that the convicted person brings to society's efforts at his reformation will no doubt play a significant role in the success or failure of those efforts, and the person who feels that his sentence was shaped by honest and scientific methods will probably have a more positive attitude than one who for some reason believes that the severity of the treatment afforded him was determined only by the fortuity of having his cause tried before a hanging judge, a soft judge, or a judge who was misinformed by an anonymous and vindictive gossip.

These same considerations would be relevant to an allied but much more general goal-the preservation of the criminal law as both the symbol and reality of justice. The process of sentencing and probation is the only aspect of the criminal law which formalizes the principle of mercy; such a lofty human endeavor should not be cloaked in secrecy but should be open as proof of its fairness and rationality. ${ }^{95}$

94 See text accompanying notes 16-35 supra.

95 See Note, Procedural Due Process at Judicial Sentencing for Felony, 81 Harv. L. Rev. 821, 838 (1968). 
Giving deference to those who clamor about the dangers of full disclosure of the contents of the presentence report: (the drying up of confidential sources, the impairment of familial relationships, the destruction of the confidential rapport ideally established between the convicted person and his probation officer), it might not be appropriate to establish a categorical rule compelling total disclosure in all cases. Perhaps what is needed in this area is more of an attitude and general disposition on the part of the judiciary in favor of disclosure, as opposed to a rigid mandate. Nevertheless, there should be a presumption in favor of disclosure that cannot be overborne by facile generalities about the inappropriateness of disclosure. If due process does indeed guarantee the right to be sentenced in accord with factually correct and intelligible information, a reviewing court can apply a balancing test yet still challenge the asserted interests in confidentiality in each case. There may be situations when the reviewing court cannot make an informed weighing of the imperatives of secrecy, but there is nothing to prevent such a court from being skeptical, for example, of an assertion that the Federal Bureau of Investigation will discontinue its aid to local authorities because its identity is revealed to a small-time crook. $^{96}$ Even in cases of genuine doubt it might be practicable to place the burden on the state to justify confidentiality.

Questions of disclosure of the data on which sentence or probation is based are very much related to the question how the convicted person should be allowed to challenge the accuracy of such data. Most judges interviewed have attempted to fashion some procedure short of a full adversary hearing that will insure fairness to the defendant. ${ }^{97}$ Their stated goal has been to accommodate fairness yet avoid placing more of a strain on an overburdened judiciary. The argument can be made that since the choice between imprisonment and probation and the length of imprisonment is solely within the trial judge's discretion and since there is no burden of proof in a sentencing procedure, nothing will be gained by forcing a more formalized procedure (such as crossexamination of the authors of the presentence report or their informants) upon an unwilling judiciary. One would hope, however, that judges directed to employ more procedural safeguards would not

96 See note 38 supra and accompanying text. There is some empirical information that disclosure will not hamper the flow of information relevant to sentencing. Thomsen, Confidentiality of the Presentence Report: $A$ Middle Position, 28 FED. Prob., Mar. 1964, at 8-10.

87 One practice of the judges when an assertion in the report is challenged is to shape sentence without regard to the disputed information. Another is to allow the probation department to oppose a request to divulge information on the basis that such action would be harmful to the defendant. Such a motion by the probation department could only be grounded upon harm to the defendant, and not upon a claim that disclosure would jeopardize a source of information. A determination of the probation department's claim is made through an in camera inspection of the report by the trial judge. If the judge finds that the probation department's claim has merit, the harmful material is deleted from the report before it is given to the defendant. The second seems the better practice. 
be so petty as to vent their displeasure by increasing the severity of treatment of those under their control. Also to be noted is that the majority of the judges interviewed thought that the occasion for factual controversy would be relatively rare. This attitude was prevalent among those who disfavored further procedural formalization as well as those who favored it. This would tend to subordinate any fear of overburdening the judiciary to the procedural protection of the convicted defendant.

The pattern with respect to the procedural context of probation revocation is very much the same: strong indication of a constitutional requirement of further formalization and a wide diversity of opinion among Philadelphia trial judges both as to present legal requirements and as to how the law ought best develop.

Diversity is unavoidable when sentencing discretion is left to the judges, and each particular judge will of necessity bring different conceptions and value judgments to the task. ${ }^{98}$ However, on such fundamental issues of procedure which are as important to defendants as the trial on guilt itself, fairness would seem to require that more definite standards should obtain.

98 This problem has received considerable attention, particularly among the judiciary. See, e.g., Rubin, Disparity and Equality of Sentences-A Constitutional Challenge, 40 F.R.D. 55 (1966) ; Zavatt, Sentencing Procedure in the United States District Court for the Southern District of New York, 41 F.R.D. 469 (1967) (sentencing conferences). 